\title{
A DIDACTIC PERSPECTIVE ON THE FALSE TREATY OF MANIPULATION - WRITTEN BY ANA BLANDIANA
}

\author{
Florina - Irina Dima ${ }^{1}$
}

\begin{abstract}
The present paper aims to underline the important role of introducing contemporary reading of autobiographical texts in high-school literature classes in Romania. It mentions the concepts of Shah Saria, Debra Edwards, and Linda Andersen, and the definitions of autobiography by Philippe Lejeune, Isabel Duran, and Karl Weintraub. For demonstration, it examines the text of the Romanian writer Ana Blandiana (a pseudonym of Otilia Valeria Coman), namely the False Treaty of Manipulation, published in 2013. The didactic generosity of this book is demonstrated with mention of the thematic stratification and uniqueness of the text, and by discussing the textual reference to the Romanian contemporary history, the connections between topics within the book, and how these might serve the interest and preparedness of teenagers for their adult life. The didactic approach of the book content involves extra-, inter-, and across-textual questions, as well as detailed passages, themes, and secondary themes relevant to the study of autobiography.
\end{abstract}

UDC Classification: 37.02, DOI: http://dx.doi.org/10.12955/cbup.v4.773

Keywords: autobiography, high-school pupil, manipulation, inter-disciplinary study, didactics, memory.

\section{Introduction}

The importance of frontier texts has grown at an international level along with receptor interest in realtime events. On the literary market in Romania, memorial writings became important immediately after the fall of the communist regime (Urian, 2005). The published diaries, memoirs, and autobiographies have been sold at an increasingly high rate. Autobiographic writings, as integral parts of revelations, have been used for several decades as didactic material in high-schools of various countries. Being defined as a "biography of a person narrated by that person herself" (Duran, 2003, website citation), "the story of a life: the name implies that the writer will somehow attempt to capture all the essential elements of that life" (Barrington, 1997, p. 22), and "the retrospective narrative of an individual's life, written by that individual, with the aim of telling the true story of his public or private experience" (Weintraub, 1978 apud Barua Krishna, website citation), an autobiography implies "the author identifying with the narrator" (Papadima, 1999, p. 31) or "the protagonist" (Lejeune, 1982, p. 193). The writer, Saria Shah (2003, p. 7), considers that autobiographic narratives help youths "to recognize certain problems of the human existence when they will confront them", at the same time giving them possible solution directions, whereas specialist Bill Broz $(2009$, p. 61) uses, as an argument, the opinion of Kirby and Kirby (2007, p. 8), according to which "memoir offers possibilities for in-depth literary study and analysis and for connecting literature to personal experience through writing". Other researchers (Edwards, 2009, pp. 51-58) identified three possible advantages in using autobiographic texts as didactic material. Therefore, such texts can represent a way of learning from the experience of others. They can underline the importance of the context in which a person lives or the situations that certain circumstances create, or both simultaneously. Nevertheless, another important aspect of studying autobiographic texts is that they help pupils/youths define themselves or to become aware of certain features (e.g. qualities, faults, or type of mentality) by relating to the "other". Furthermore, in a totalitarian society the autobiography "becomes a way to testify about oppression and to invest with power the subject by his cultural recognition and assignment" (Andersen, 2007, p. 104 apud Jennifer Muchiri, 2014, p. 89), and therefore such texts are recommended to high-school pupils because they bring together general historical and cultural elements that are subscribed to in particular contexts, for the young readers attention.

\section{Data and methodology}

One Romanian memoir book for high-school pupils to read and familiarize themselves with recent history of the country based on an author's life is the False Treaty of Manipulation, by Ana Blandiana (literary pseudonym of Otilia Valeria Coman Rusan). The title refers to an intoxicating manipulation,

\footnotetext{
${ }^{1}$ Florina - Irina Dima, University of Bucharest, Faculty of Letters, Bucharest, Romania, irenadima@yahoo.com
} 
which the author had tried to escape during her entire life and mentions countless moments when others tried to use her or her reputation in a particular way. Although the text was not written explicitly to educate people, it provides a history lesson by way of combining the country's history with the story of the writer's private life. It also provides a literature lesson with Ana Blandiana using a literary-subjective form of memoir discourse. The bond between themes of this book and its teaching in schools is relevant with certain passages, written by the author to clarify her own thoughts and feelings, suitable for modern youth, who have difficulty in understanding the mechanisms of communism and specific mentalities of a totalitarian regime. A suggested section, as an example, is "Who knows what a mineriad is?". This originates from a real encounter of Ana Blandiana with highschool pupils, a few years ago, when she was invited to explain how The Sighet Memorial was born. The author's stupefaction towards the ignorance of the adolescents regarding the communist theme motivated her to develop an interior monologue before speaking because she wanted to establish the best way to approach the subject (Blandiana, 2013, p. 146).

A similar passage called: "A cloned world" starts with the intimidation felt by modern youth as they meet with her. The explanation given by the author is that the relationship with the mere person Ana Blandiana is preceded by a sense of the celebrity status she gained as a writer and fighter for freedom. Therefore, the author presents a few unpleasant and absurd situations she found herself in because of the image others formed of her through her literary and political activity, without meeting or having knowledge of her in person. The difference between the mental representations of others towards her and her actual identity is obvious and underlines the authenticity of the human being hidden behind the pseudonym of "Ana Blandiana", and of the human being who wants to testify of the truth: "The only aspect of memory which interests me is finding out the truth" (Blandiana, 2013, p. 260), but not being able to omit the unhappy experiences which she has endured because of the mentalities of others. In this way the readers are guided towards discovering the context of some events of recent history from the point of view of the author feelings; the author being the narrator and main character in their story.

Beyond these fragments, False Treaty of Manipulation is a memoir of the Romanian society in terms of the communist and post-communist period, filtered through the eyes and mind of the author. The discussed themes of this kind are diverse, but all represent the "dark" communistic background, within the general theme of the book. Therefore, the author presents, through her own life experiences, a connection between good and bad, between people in terms of truth, betrayal, memory, and the human condition, between human beings and the history of time, childhood, and adolescence, and the consequences of intimidation strategies of the Securitate (the secret police agency of Communist Romania), which included censorship, unfair arrests, political events of the post-December-revolution, and certain events in the life of some cultural or political personalities.

The connection between past events and her present feelings is constant because of the unpleasant events or injustices lived through and still felt by Ana Blandiana today. The re-running of memories permanently influences her affective memory and this is why the author starts with the event that most profoundly affected her, namely her father's unfair arrest, which proceeded to affect the entire Coman family. The sufferance she experienced matured her, but moreover, the author endured many additional injustices, one being the rejection of her file when she registered for Faculty admission. The reader discovers, through the text, the childhood and adolescence memories of the author; an author whose wings had been broken due to her father's arrest because he was considered to have offended the communist regime by his provoking attitude in his role as a priest. The feeling of guilt was constantly experienced by Ana Blandiana, since the secret police had searched her parent's home, before the arrest and intentionally placed a pistol in the furniture drawer exactly when she left the house, in spite of her father insisting she stay inside during the checking. Aged only five at that time, she has, in hindsight, realized that leaving the house at that time had its consequences and this revelation profoundly affects her, especially because she loved her father enormously. Therefore, the text reveals the relationship between father and daughter from the moment of his first arrest until his death after a domestic accident. Nevertheless, this girl does not give up easily. She fights for freedom through writing, and alongside her soon-to-be husband, Romulus Rusan. She uses the literary pseudonym of "Ana Blandiana", inspired by the village name of where her mother was born, i.e. Blandiana. In this way, her father, who is imprisoned at the time, hears about the publishing of Ana's 
first poems from his cell colleagues, and recognizes his daughter as the true author. His daughter discovers this later. Unfortunately, detention affected the health of the priest, Coman, like that which affected most intellectuals imprisoned during the communist regime. The arrest and subsequent imprisonment of her father involved difficult moments for the writer and left deep scars in her soul, though she became stronger and more sensitive. Her motivation for becoming a writer mostly arose from the imprisonment of her father and his silence after his returned home. The questions she had and did not dare ask him left a void in her soul and she aimed to fill that through writing. Blandiana (2013) wrote the following:

Then I discovered my own destiny - mine as a human being different from the others, not only because of what I've been through, but also because of what my parents and grandparents had been through - a destiny in which I were to be from that time on the daughter of my father's untold pain. [...]. Then, out of my Father's surprise and out of my own surprise and supposition the writer that I were to become starting with the second volume was born (p. 30).

This kind of revelation could be used for a discussion theme during literature classes because it facilitates an understanding of human experience that ultimately affects a person's destiny. Being certain, since your adolescence, of your desire to be a writer is proof of an awareness of your own destiny, but is also a huge responsibility, especially when one has to write from within a totalitarian regime. Moreover, the connection between freedom of speech and the annulment of this freedom facilitates an understanding of two fundamental concepts of a totalitarian regime: censorship and interdiction. The materialization of these two terms in the life of Ana Blandiana had consequences, not only during her professional, but also during her private life. Therefore, through the reading of this book, a pupil can observe the effects of interdiction on a writer's life. A section on this topic is suggestively called- "Traviata". The title relates to the role of Violetta Valery, in the work of Giuseppe Verdi, in which, because of her reputation of a courtesan, Violetta is asked to leave her lover in order not to affect his social position. In a similar way, the Traviata section portrays the moment in which Dumitru Isac, chief editor of the Tribune magazine, asks Ana Blandiana to end all relations with Romulus Rusan, who was another young writer at the time, because her marriage with him would destroy his career. The bold request by Isac follows receipt of an official letter to the magazine, declaring Ana Blandiana as no longer having the right to publish papers because she was "the daughter of an enemy of the people". In spite of received warnings from youths, she continues and marries Romulus two days later. This decision had consequences for them both because each endured humiliation at the magazines' trade union meetings. From that moment Ana Blandiana is rejected, not only by literary magazines, but also by those she considered close, including her work colleagues from the magazine and personal friends. Blandiana (2013, p. 101) mentions "because those four years of interdiction to sign and rejection from registering to college have placed me out of the literary circles and I remained outside even after I started again to publish".

The consequences affecting her private and social life are presented in detail by the writer, who compares being isolated and rejected with being in purgatory, from whence she frees herself after four years following the lifting of her publishing interdiction.

\section{Results and Discussion}

The didactic generosity of those life experiences allows a teacher to initiate captivating debates among adolescents, especially because the text depicts realities from recent history of Romania. Also, a pupil can observe the dominant type of mentality of a totalitarian regime, where people are not free and are guided by fear. This is why, when Ana Blandiana suffers an injustice or is verbally attacked by her superiors, others do not react and their silence aggravates her situation. Blandiana (2013, p. 54) mentions: "How could they remain silent and in what extension the fear background could have represented an excuse for their silence." A parallel between the communist period and modern day, in terms of freedom, rights, and citizen duties, could not only show the differences between the life of a writer or journalist of past and present but also the tight relationship between a human being and the historical context in which they live. Moreover, an adolescent could reflect upon the term "independence" - so often used today - though total independence remains a utopia because human beings find it difficult to live outside the boundaries of faith/religion, political regime, society, or family. The False Treaty of Manipulation speaks precisely about these matters. 
Another perspective for discussing the book in class is the author's view on Mihai Eminescu's writings in time. In the section, "3rd Degree Meeting", the author recalls the way Romanians chose to keep the portrait of Mihai Eminescu in their collective memory and mentions how "his degree of popularity is more a feature of the epoch than the great poet himself" (Blandiana, 2013, p. 229). According to some recent statistics, only $18 \%$ of the country's population knows of Eminescu and his writings, and this strongly indicates the lowering of literary interest. The author recounts how she attempted, with a group of writers, to oppose the manifestations dedicated to the 15 January, a day of the writer's birth date, that were a stereotype of Romanian communistic ways. Her protest, together with that of her colleagues, against the illiterate speeches by communists on that day regarding the poet Eminescu, involved placing a garland in front of the Romanian Athenaeum in Bucharest and the dressing of Eminescu's statue in a vegetable coat. Ana Blandiana notes the difference between the celebration of the great poet by way of communism and that during the post-December period, by mentioning that she cannot understand nor accept the desire of some intellectuals to denigrate the image of Eminescu after the fall of the communist regime. In fact, the author notices that the authenticity of the great writer was affected by the way each epoch related to its image, according to its own interests. For example, the poem "What I wish you sweet Romania" was vulgarized by its completely un-poetical usage within the text of Alecu Russo, "The song of Romania" (Blandiana, 2013, p. 230).

The method of extra-, inter-, and across-textual requirements (Hartman, 1992, pp. 295-311) can be related to the three stages of reading: pre-reading, reading, and post-reading. Table 1 in Appendix, a few examples of questions point to general information about the communist regime (extra-textual), others to the similarities and differences between autobiographic texts with a theme of experiences under a totalitarian regime (across-textual), and the remaining to the textual content (inter-textual). The extra-textual questions relate to the pre-reading stage, the across-textual ones appear adequate for the reading and post-reading stages, while the inter-textual questions require the closing of the reading, and therefore are recommended for the post-reading stage. This kind of didactic approach allows not only the knowledge of the mere text, but also the shaping of a general view on the embodiment of Romanian communism.

The text written by Ana Blandiana allows readers to look at various contemporary and cultural personalities from a perspective of her real-life contact with these identities. For instance, people of cultural or political background, such as Ștefan Bănulescu, Eugen Ionescu, Mircea Eliade, Emil Cioran, Gabriela Adameșteanu, Geo Bogza, Corneliu Coposu, Mircea Dinescu, Emil Constantinescu, Silviu Brucan, and Ion Iliescu, are represented as the writer perceived them at the time of their encounter. However, the most detailed representation of a writer by the author concerns the writer, Romulus Rusan, her husband. A reader can observe, in various contexts, the unconditional love and protection her husband endeavors to offer to his wife and the crossing over of the destinies of these two people is the thread that binds together the micro-narratives within this confession-type book. The turning points in the life of Ana Blandiana were countless and this is why her marriage strengthened over time, resilient to all difficulties. From the first publishing interdiction to the last intimidating call she received, from rumors to threats, phone interceptions to tracking and surveillance, offensive letters to injurious articles, insulting words in the street to resentment of work colleagues, she endured and survived with the tireless effort of Romulus Rusan, her main confident, protector, and life partner. Since the age of 18, Romi, the nickname given to him by the author, had always been there for her and this relationship, although not explicitly noted, offered her courage and support. The author allows the public to see the consequences of the secret police techniques that were used to intimidate her over her private life as well as her mental state over time. The injustices endured have not been forgotten. They resound so loudly in the mind and soul of Ana Blandiana because they are difficult to forget. Tears were shed after the union trade meetings in which she was denigrated. Her writings liberate these grievances. The transcript of the author's feelings has a double purpose in this case: one, to freely speak about oneself - even if, at the emotional level, the liberation of memories is like opening a wound - and two, to reconstruct the historical truth, from a personal perspective, as a participant or only witness to the pre- and post-December historical events. Recollections are often unpleasant, but the author knows they should not deter writing, because she owes it to herself to transcribe every detail that happened and how she sees it today. From this point of view, the passage referring to obvious 
fundamental values of the Romanian contemporary society, which, whenever it analyses elites "doesn't take into consideration the writers", is relevant (Blandiana, 2013, p. 229).

Beyond the privations and atrocities of a totalitarian regime, the beginning of democracy in the postDecember period was little better, and, as such, had disappointed Ana Blandiana. Attempts by others to use her image, the struggle to create something politically stable, and the various calumnies placed upon her, diminished her enthusiasm. Nonetheless, these exertions also guided her in another direction: the founding of the Sighet Memorial, with her husband, Romulus Rusan. This achievement and her writings remained her focus, together with attending conferences and poetry festivals. The work of Ana Blandiana is internationally acknowledged and she is invited to important events organized by various universities. That is why she says: "she feels being a writer more abroad", although she never wanted to leave the country permanently. There is also the issue of the Romanian writers in exile who suffered because they had to leave the country in order to be free. Throughout the text, a reader is introduced to famous writers, such as Mircea Eliade and Eugen Ionescu, who obviously pine for Romania. The exile for these writers has been a form of sufferance, one which Ana Blandiana confesses she could never endure. The author's unique approach reflects in the composition of the book, which does not follow the classical pattern of an autobiography. It involves a sequence of micro-narratives and reflections that are not in chronological order. Although one can notice the evolution of the character-narrator since childhood towards maturity, the joining of the past with present elements is inevitable when the writer lives the memories. The definition given by Ana Blandiana "to memory" underlines its vital importance, because it reincarnates the truth, whereas the totalitarian regimes manipulated the truth. The idea of freedom and assuming responsibility for one's actions, in terms of the good, the bad, the beautifully, and the ugly, are other key elements of the author's reflections, because they contribute to the shaping of the overall textual meaning. The image of the bad in the world is carefully portrayed by Ana Blandiana, through subtle remarks referring to the variety of forms embodied by "evil". The term, manipulation, becomes the semantic center of the book, because it represents the source of evil. The lack of reaction, the silent acceptance of injustices and the desire to persuade others become forms of manipulation, in which the performers are the manipulated or the manipulators. The biography of Ana Blandiana is a testimony of the fight against manipulation, a fight the author has not always won. Nevertheless, her retrospective look has helped her to be aware of the most difficult moments she endured and this may be the reason for her inclusion in the first pages of her narration of an anti-manipulative verse that is a quotation from Erasmus of Rotterdam and which is a significant reminder placed over her writing desk - "don't let yourself be used by nobody" (Blandiana, 2013, p. 8).

\section{Conclusion}

The way in which the book reflects the theory of memoir discourse, at the level of the connection between memory, recollection, forgetting, auto fiction, confession, and documentation, can facilitate an understanding of frontier texts, and at the same time underline the importance of memoir genres and the contribution of these, not only in the literary, but also to history. It is obvious that literature and history are complementary domains in the book examined in this article because the narrated situations are embodied in a literary form, since the author is firstly a poet (Vultur, 2014, website citation). Therefore, a teacher of literature can conceive a project, a study case, or an investigation, such as that entitled: Reinterpreting a biographic path - political, historical, geographical, literary, ethical digression (Popescu \& Stănescu, 2013, pp. 64-65). This kind of theme would allow Romanian pupils from 12th grade to conduct research within a chapter dedicated to autobiographical writings, using The dynamics of some genres: journals, memoirs - works published after 1990 (School curriculum for Romanian Language and Literature, 2006), to thematically structure the text of Ana Blandiana and to inter-connect different areas within the biography of a personality. Moreover, the pupils would learn how they could appropriate this kind of book and relate to the first person narrative text. They could also understand how they might contextualize a human experience or how they could interpret historical, social, and political events. In this way, the dynamic aspect of reading and its duality is important because it also helps in building meaning and decoding and or deciphering the textual significance. Therefore, the study of an autobiographic text, such as the False Treaty of Manipulation, allows an understanding of recent (national) historical events, the development of 
youths' critical thinking, the power of example with the evolution of the protagonists, and maybe most importantly, indirectly guides adolescents towards an understanding of the world they live in.

\section{Acknowledgements}

I would like to express my deep gratitude to Professor Liviu Papadima, my research supervisor, for his patient guidance, enthusiastic encouragement, and useful critiques of this research work.

\section{References}

Andersen, R L. (2007). Autobiography and the feminist subject, Cambridge University Press, 119—135, apud Jennifer Muchiri (2014) The Intersection of the Self and History in Kenyan Autobiographies, Eastern African Literary and Cultural Studies, 1:1-2, 83-93, DOI:10.1080/23277408.2014.98016. Retrieved February, 25, 2016, from http://www.tandfonline.com/doi/pdf/10.1080/23277408.2014.980161 , accessed: 03.06.2015.

Barrington, J. (1997). Writing the Memoir: From Truth to Art, Eighth Mountain Press, 189. Retrieved from http://www.writersandeditors.com/memoir_biography_and_corporate_history_58068.htm\#bookmark5 Blandiana, A. (2013). False Treaty of Manipulation, Humanitas, București.

Broz, B. (2009, summer). Memoir: Reading Life, The ALAN Review. The Professional Resource Connection, 59 - 64 Retrieved February, 24, 2016, from https://scholar.lib.vt.edu/ejournals/ALAN/v36n3/pdf/broz.pdf.

Duran, I. (2003, April 1). Autobiography. The Literary Encyclopedia. Retrieved February, 22, 2016, from http://www.litencyc.com/php/stopics.php?rec=true \&UID=1232

Edwards, D. (2009). Tracing Literacy Journeys: The Use of the Literacy Autobiography In Preservice Teacher Education, Australian Journal of Teacher Education, vol. 34 (4), art. 6, http://dx.doi.org/10.14221/ajte.2009 v34n4.6

Hartman, D. K. (1992). Intertextuality and reading: The text, the reader, the author, and the context. Linguistics and Education, 4(3-4), 295-311.

Kirby, D. L., \& Kirby. D. (2007). New Directions in Teaching Memoir: A Studio Workshop Approach, Portsmouth, Heinemann, 8.

Lejeune, Ph. (1982). The Autobiographical Contract, in French Literary Theory Today. Tzetvan, Todorov, ed. Cambridge: Cambridge University Press, 193.

Papadima, L. (1999). Literature and communication. The relation author-reader in the 1848 and post-1848 prose, Collegium Litere, Polirom Publishing House, Iași, 31.

Popescu, C., \& Stănescu, A. (2013). METHODOLICAL INTER-SUBJECT GUIDE - Education through reading, Invest in people! EUROPEAN SOCIAL FUND, Sector Operational Program for the Developing of Human Recourses 2007 - 2013, Axis "Education and professional formation in sustaining the economic growth and the developing of the society based on knowledge ", Major intervention area: 1.3. - Developing the human resources in education and professional formation". The title of the project: e-Formation - Integrate competences for the knowledge society, Beneficiary: SCHOOL INSPECTORATE OF CLUJ COUNTY, Contract identification number: POSDRU/87/1.3/S/55336, 64-65.

School curriculum for Romanian Language and Literature (2006). Ministerul Educaţiei şi Cercetării/The Education and Research Romanian Ministry, Consiliul Naţional pentru Curriculum/The National Council for Curriculum, Programe şcolare superior al liceului. Limba şi literatura română clasa a XI-a/Curriculum for the XII th grade, Anexa nr. 2 la ordinul ministrului educaţiei şi cercetării nr. 3252/13.02.2006/Annex no.2 of the Minister's Order no. . 3252/13.02.2006.

Shah, S. (2003). The storyteller's daughter, New York: Anchor, Random House, 7.

Urian, T. (2005). Contemporary readings: The writer and his masks, http://www.romlit.ro/ scriitorul_i_mtile_sale, accessed: 23.05.2015.

Vultur, S. (2014). Ana Blandiana or about time as intensity, Revista 22. Retrieved February, 25, 2016, from http://www.revista22.ro/ana-blandiana-sau-despre-timp-ca-intensitate-36912.html.

Weintraub, K. J. (1978). The Value of the Individual: Self and Circumstance in Autobiography. Chicago, IL: University of Chicago Press. Retrieved February, 26, 2016, apud Barua Krishna, Some principles of a autobiography, PPT, from http://documentslide.com/documents/s-ome-p-rinciples-of-a-utobiography-krishna-barua-professor-deptof-humanities.html, accesed 03.02.2016. 


\section{Appendix}

Table 1: Example of extratextual, intertextual and intratextual texts, starting from Ana Blandiana's False Treaty of Manipulation

\begin{tabular}{|l|l|}
$\begin{array}{l}\text { Objectives (according to } \\
\text { the Romanian Language } \\
\text { and Literature } \\
\text { Curriculum, Grade XII) }\end{array}$ & $\begin{array}{l}\text { - cultivation of reading as a pretext for documentation / investigation/ } \\
\text { solving; } \\
\text { - developing linguistic, written and spoken skills; } \\
\text { - developing context placement, analysis, summarizing and } \\
\text { comparison skills; } \\
\text { - developing thinking on a superior level (critical, creative analysis/ } \\
\text { thinking as well as analysis/thinking in comparison with others) } \\
\text { - developing cultural skills }\end{array}$ \\
\hline I. Questions / extratextual & $\begin{array}{l}\text { Research about communism in Romania and about the censorship in } \\
\text { that era. } \\
\text { Who is the communist leader you have heard about? } \\
\text { What did you learn from your parents and grandparents about the } \\
\text { communist regim? } \\
\text { Which is the meaning of Totalitarian regim ? What about the } \\
\text { leader's cult? } \\
\text { Research about Romanian writers in exile / who have lived in exile. }\end{array}$ \\
\hline II. Questions / intertextual & $\begin{array}{l}\text { Which other boarder texts (autobiographies, journals) about } \\
\text { communism/ life under the communist regime have you read? } \\
\text { Watch The Memorial of Suffering documentary or Mao's last dancer. } \\
\text { The position of a human being towards history is essential in an } \\
\text { autobiographical text. Compare, from this perspective, a fragment } \\
\text { from Ana Blandiana's text with a fragment from the following books: } \\
\text { Nicolae Steinhardt's Diary, Anna Frank's Diary, Mihail Sebastian's } \\
\text { Diary. }\end{array}$ \\
\hline Source: Author & $\begin{array}{l}\text { Write a short essay about the importance of a historical context in the } \\
\text { life of an individual } \\
\text { How is the Romanian society under the communist regime depicted } \\
\text { by the author? } \\
\text { How did the censorship function in that time? } \\
\text { Which intimidating techniques did the Securitate use? } \\
\text { Whom of the Romanian authors in exile did the writer meet? } \\
\text { What means manipulation in her conception? How does it manifest? } \\
\text { How is the post revolution world presented in False treaty of } \\
\text { manipulation? Which forms does it take? } \\
\text { What is the purpose of this book? } \\
\text { Do you consider this book a document? }\end{array}$ \\
\hline III. Questions/ intratextual
\end{tabular}

